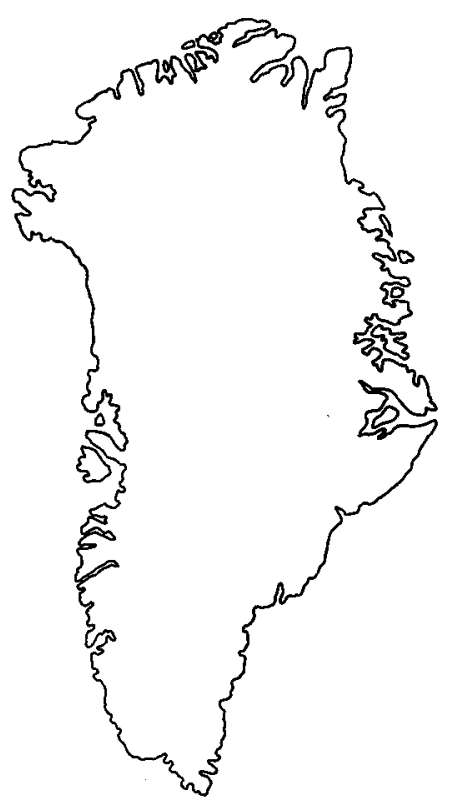

\title{
Autecology and systematics of a new Silurian anomphalid gastropod from western North Greenland
}

\author{
John S. Peel
}

Grantlandispira christiei gen. et sp. nov. is an anomphalid gastropod characterised by a shallowly cyrtoconoid spire, subsutural sinus and angular periphery. General form of the shell and the massive funicle within the umbilicus indicate a close relationship to Pycnomphalus Lindström, 1884 and this genus, together with Grantlandispira, and possibly Turbocheilus Perner, 1907 are referred to a new subfamily, Pycnomphalinae. Shell morphology and the radial aperture suggest that Grantlandispira was an infaunal or semi-infaunal ciliary feeding gastropod, similar in its life style to Umbonium Link, 1807.

J. S. P., Grønlands Geologiske Unders $\emptyset$ gelse, $\emptyset_{\text {ster Voldgade }}$ 10, DK-1350 København K, Danmark.

The shell of anomphalid gastropods is characterised by the development of a thickening of the shell along the umbilico-basal margin of the aperture. This may be a callus, closing the umbilicus in the mature snail, or an adaxially directed flange, termed a 'funicle', which extends from the umbilico-basal region of the whorl into the umbilical cavity. With growth, the funicle forms a spiral ridge or shelf within the umbilicus and, when well developed, may effectively close off the umbilicus. A funicle is also present in other gastropod groups, e. $g$. the pleurotomariins Liospira Ulrich \& Scofield, 1897, and Angyomphalus Cossmann, 1916, and its development may indicate parallel adaptation between the lenticular pleurotomariins and the often similarly coiled anomphalids.

Grantlandispira gen. nov., described below from the Silurian of Kap Tyson, western North Greenland (fig. 1), combines a slightly cyrtoconoid spire with a well developed funicle and an unusual, sinuate, outer lip. The new genus is closely related to another Silurian gastropod, Pycnomphalus Lindström, 1884, in which, however, the funicle is combined with an orthocline lip and rotelliform shell. This similarity is emphasised by the creation of a new subfamily, Pycnomphalinae, of the Anomphalidae, to include the two genera and possibly also Turbocheilus Perner, 1907. 


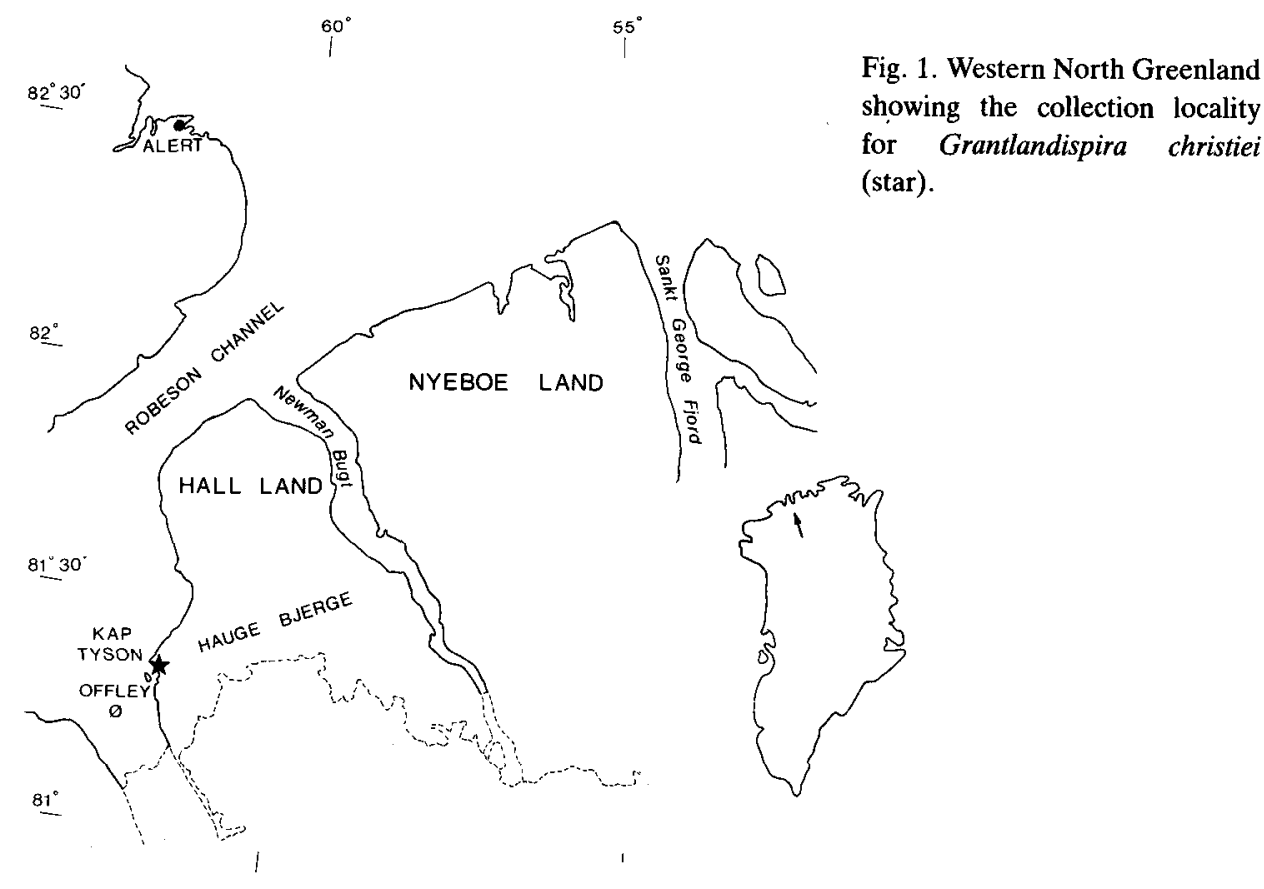

Class Gastropoda, Subclass Prosobranchia, Order Archaeogastropoda, Suborder Trochina

Family Anomphalidae Wenz, 1938

Discussion. McLean (1981) considered that members of the superfamily Anomphalacea may have had a similar pallial complex to extant trochaceans. Elaboration of this viewpoint suggests that this group of Silurian-Permian genera (Knight et al., 1960) should be given family status within the superfamily Trochacea rather than be recognised as a separate superfamily. Genera placed in the Anomphalacea and its single family Anomphalidae by Knight et al. (1960) appear heterogeneous with respect to the form of the aperture, which varies from radial, with an orthocline outer lip, to tangential, with quite strongly prosocline growth lines.

This heterogeneity promotes recognition of two subfamilies within the Anomphalidae. In the subfamily Anomphalinae, the aperture approaches tangentialism and the outer lip is usually prosocline, although in some genera this may be modified to prosocyrt immediately below the suture with the previous whorl. In the Pycnomphalinae, the aperture is subradial and the outer lip varies from opisthocline, with a shallow subsutural sinus, to near orthocline. A well developed funicle is often characteristic of pycnomphalinids.

\section{Subfamily Anomphalinae Wenz, 1938}

(nom. transl. herein, ex Anomphalidae Wenz, 1938)

Diagnosis. Anomphalids with near tangential apertures and a generally prosocline outer lip. The umbilicus is often partially closed by callus, although some genera possess a narrow circumbilical funicle. 


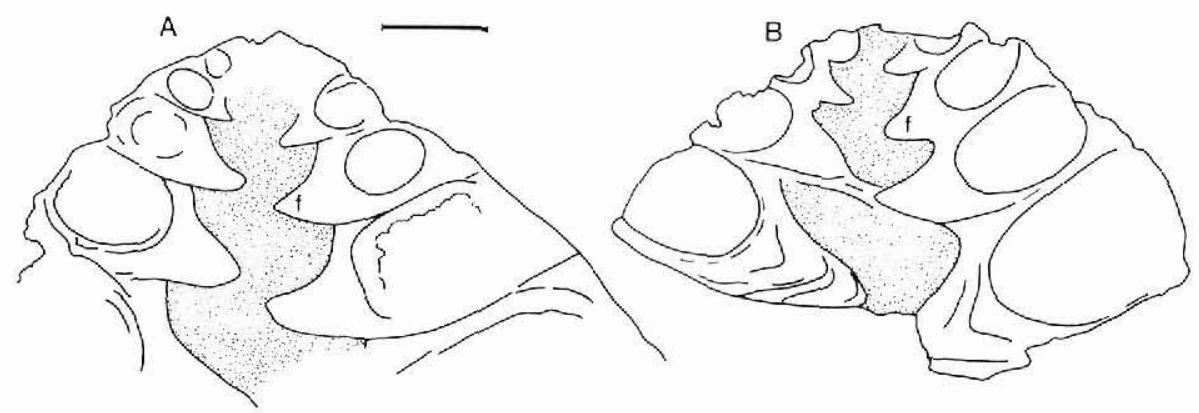

Fig. 2. Camera lucida sketches of axial cross-sections in Grantlandispira christiei showing the sediment filled umbilicus (stippled) and the well developed funicle (f). The shell wall and the whorl interior is often strongly recrystallised, such that circular boundaries shown within the recrystallised shell should not be automatically interpreted as the surface of the shell on the whorl interior. A, the holotype; B, the paratype. Scale bar is $5 \mathrm{~mm}$.

Discussion. In addition to Anomphalus Meek \& Worthen, 1867, this subfamily includes Isonema Meek \& Worthen, 1866, Turbinilopsis de Koninck, 1881 and Straparella Fischer, 1885, and possibly Tychonia de Koninck, 1881 and Sosiolytes Gemmellaro, 1889. Knight et al. (1960) placed Antirotella Cossmann, 1918 as a synonym of Anomphalus and also tentatively placed Eiselia Dietz, 1911 within the Anomphalidae. The latter appears to be based on materials now lost, but Knight's (1941) re-illustration of the original figure from Dietz (1911) suggests a low spired form with a strongly prosocyrt outer lip and broad, rounded folds or varices. Eiselia cannot be satisfactorily located within the Anomphalidae and probably does not belong to the family. Anomphalinids range from the Early Devonian to the Carboniferous and ?Permian (Knight et al., 1960).

\section{Subfamily Pycnomphalinae nov.}

Diagnosis. Anomphalids with subradial apertures in which the outer lip varies from near orthocline, to opisthocline with a subsutural sinus. A prominent funicle is often well developed within the umbilicus.

Discussion. This subfamily includes Pycnomphalus and Grantlandispira, and possibly Turbocheilus. The type species of Pycnomphalus does not have a strongly developed funicle, but this feature is well seen in the North American species $P$. solarioides (Hall, 1852), as figured by Whiteaves (1895, pl. 13, fig. 6). A strong funicle is also present in Grantlandispira (fig. 2). In Turbocheilus, the umbilicus is apparently closed by a plug of callus (Knight, 1941, p. 370, fig. 30), but the form of the shell and its aperture suggests placement together with Grantlandispira and Pycnomphalus. As currently conceived, the subfamily Pycnomphalinae appears to be restricted to the Silurian. 


\section{Grantlandispira gen. nov.}

Type species. Grantlandispira christiei gen. et sp. nov.

Derivation of name. From 'Operation Grant Land 1965-1966', a joint Canadian-Danish geological reconnaissance programme in Ellesmere Island, Canada, and adjacent western North Greenland (Christie, 1966; Dawes, this report; Dawes \& Peel, this report). Grant Land is an early name for northern Ellesmere Island. The name persists in the Grantland Mountains.

Diagnosis. A gastropod of moderate size with shallowly cyrtoconoid spire and shallowly convex base; the wide umbilicus is almost totally closed by a massive funicle. The whorl profile is inclined and shallowly concave below the suture with the previous whorl, and passes around the angular periphery onto a shallowly convex base. The aperture is radial, with a subsutural sinus in the opisthocline outer lip.

Discussion. Grantlandispira is closely related to Pycnomphalus, originally described by Lindström (1884), from the Silurian of Gotland, Sweden. P. obesus Lindström, 1884 is, however, clearly distinguished from Grantlandispira by its rotelliform shell, with rounded almost globose whorls, and a near orthocline outer lip. Turbocheilus, also a Silurian form, has a similar shell to Pycnomphalus. The umbilicus, however, is often completely closed by callus and a shallow subsutural sinus is well developed on the slightly shouldered whorl profile. The sinus in Turbocheilus is much more shallow than in Grantlandispira.

Other genera included within the Anomphalidae by Knight et al. (1960) and here referred to the subfamily Anomphalinae, have a quite strongly prosocline outer lip, unlike the opisthocline lip of Grantlandispira.

\section{Grantlandispira christiei gen. et sp. nov.}

Figs 2-4

Derivation of name. For Robert Loring Christie, Geological Survey of Canada, leader of 'Operation Grant Land 1965-66', geologist and arctic historian, in appreciation of his contribution in arctic Canada and northern Greenland.

Material. The present description is based on two specimens. The holotype, MGUH 16.566 from GGU sample 82626, and the figured paratype, MGUH 16.567 from GGU sample 82619, were collected in 1965 by J. H. Allaart and P. R. Dawes (Geological Survey of Greenland) at Kap Tyson, Hall Land (fig. 1), from Lower Silurian limestones of the Offley Island Formation (Hurst, 1980; unit 10A of Dawes \& Peel, this report).

Both the holotype (figs 3B,C, 4) and the figured paratype (fig. 3A,D) are imperfectly preserved. The former is broken along a plane almost parallel to the axis of coiling, such that the spire is only well preserved on one side; the broken side has been ground away to show an axial section through the umbilicus in the earlier whorls (fig. 2A). The final whorl of the holotype is preserved only as an internal mould; the base is poorly known. The upper surface of the figured paratype, a smaller specimen, is abraded, but the base is relatively well preserved. This specimen has also been ground down on one side, to show an axial section through the umbilicus (fig. $2 \mathrm{~B}$ ). The holotype was partially overgrown by a stromatoporoid (now prepared away), but there is no evidence to suggest that this relationship was other than post-mortem.

Description. A biconvex multiwhorled gastropod of subequal dimensions in which the spire 

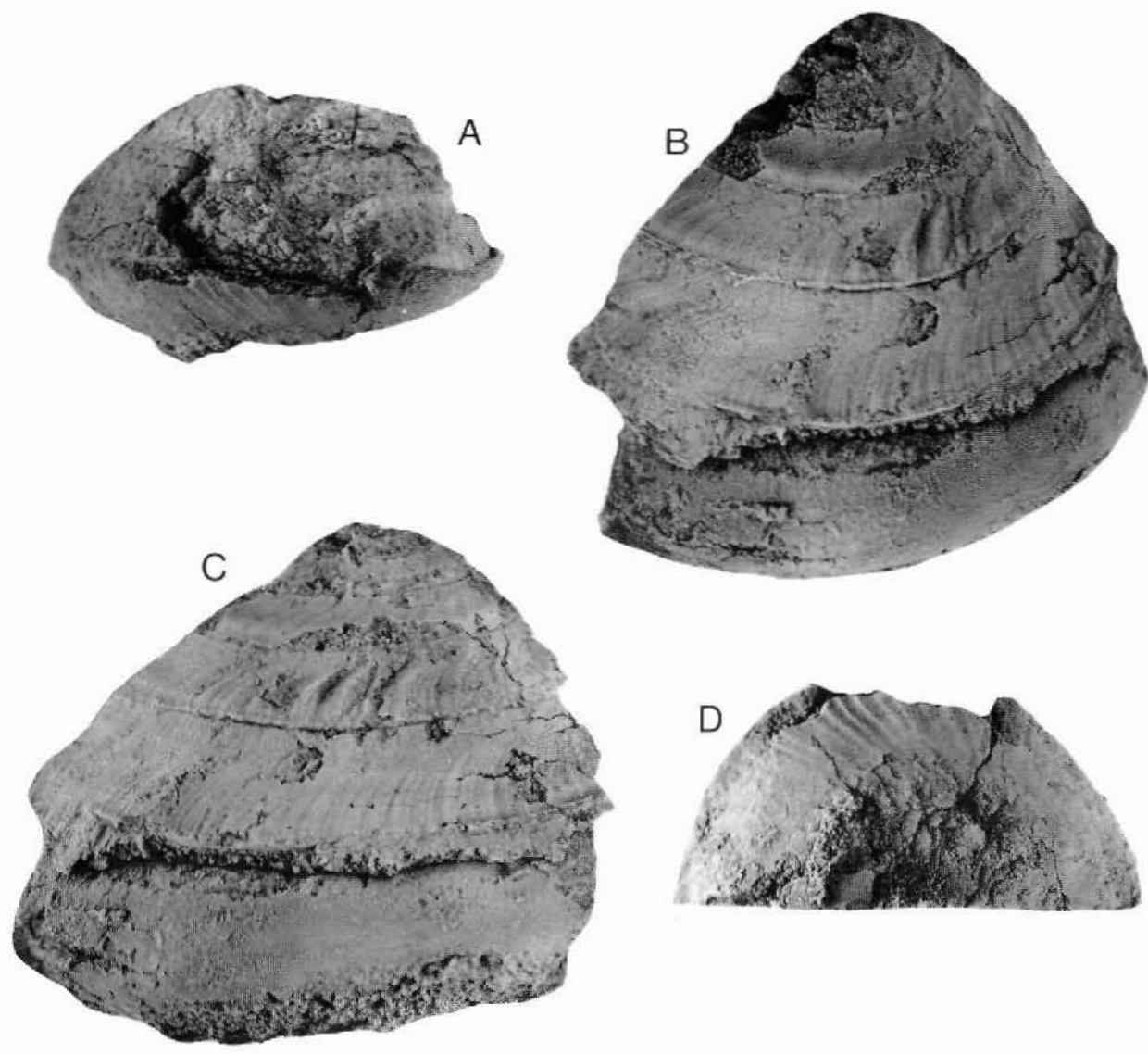

Fig. 3. Grantlandispira christiei, Silurian, Offley Island Formation, near Kap Tyson, Hall Land, $\times 2$. A . D, MGUH 16.567 from GGU sample 82619, paratype. in lateral (A) and basal (D) views to show the eroded upper surface and shallowly convex base; the lower flat surface in D represents the ground axial plane (fig. 2B). B, C, MGUH 16.566 from GGU sample 82626, holotype, in oblique lateral (B) and lateral $(\mathrm{C})$ views; the form of the spire in $\mathrm{B}$ is influenced by the grinding of an axial surface (fig. $2 \mathrm{~A}$ ).

accounts for almost two thirds of the total height. The base is shallowly convex; the spire is shallowly cyrtoconoid. The umbilicus is wide, accounting for nearly half of the shell width, when measured at the umbilical suture (fig. 2), but it is essentially closed by a massive funicle which represents a thickening of the umbilical whorl. The nucleus and the earliest whorls are unknown. The whorl cross-section at later growth stages is elliptical, slightly wider than high. The upper whorl surface is shallowly concave below the slightly adpressed suture, but becomes shallowly convex at a weak shoulder located immediately above the narrow, carinate, peripheral angulation (fig. 4). The aperture is subradial. The outer lip is orthocline immediately below the suture, but rapidly becomes opisthocline, with adapertural convexity, to delimit a well-marked subsutural sinus (fig. 4). The basal lip sweeps back, with adapertural convexity, from the periphery toward the umbilicus (fig. 3D). Ornament is of 


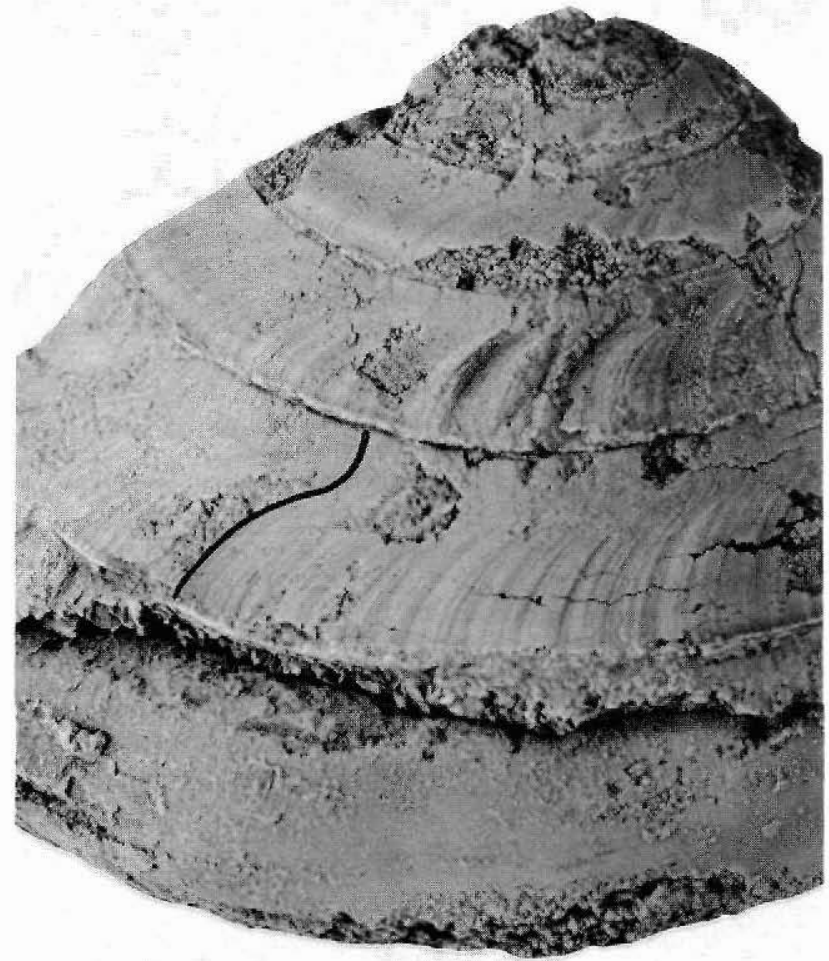

Fig. 4. Grantlandispira christiei, the holotype, in oblique lateral aspect to show the form of the outer lip (one growth line is inked), the adpressed whorls and the suprasutural shoulder, $\times 3$.

fine growth lines which become rugose on the basal surface; a few very fine spiral striae are visible on the upper whorl surface. The shell is relatively thin on the upper whorl surface, but massively thickened on the umbilical wall; its structure is not known.

Discussion. Pycnomphalus obesus Lindström, 1884, the type species of Pycnomphalus, is well described by Lindström (1884) and Knight (1941). It is apparently a smaller species than Grantlandispira christiei from which it is readily distinguished by its rotelliform coiling, with a low spire and convex periphery, and near orthocline growth lines. P. solaroides (Hall, 1852), as described by Whiteaves (1895) from the Guelph Formation of Canada, is also lower spired than Grantlandispira and shares the rounded periphery seen in the type species. It is a much larger species than $P$. obesus, with its diameter of more than $5 \mathrm{~cm}$ being somewhat larger than the available specimens of $G$. christiei. The umbilical funicle in $P$. solaroides shows a similar degree of development to that described here in $G$. christiei, but in the cross-section of the Canadian species illustrated by Whiteaves $(1895$, pl. 13, fig. 6) the funicle is strongly curved adapically into the central part of the umbilicus; in G. christiei, the funicle lacks this adapical curvature.

Lindström (1884) also described Pycnomphalus acutus and $P$. trochiformis as new species of Pycnomphalus. The former is a lenticular species with a peripheral carina quite reminiscent of Grantlandispira christiei in terms of its opisthocline growth lines on the upper whorl surface and subsutural sinus. A funicle is developed but does not serve to close the 
umbilicus, as in G. christiei. P. acutus may prove to be a species of Grantlandispira. Lindström (1884, p. 154) speculated that this species from the Slite Beds of Gotland could be identical with Platyschisma helicites Sowerby in Murchison, 1839, from the Late Silurian of the Welsh Borderlands, but the latter is a Turbocheilus (Peel, in press). P. trochiformis Lindström, 1884, is trochiform rather than rotelliform, a significant change in coiling style from the type species $P$. obesus. The upper whorl surface shows a broad, shallow sinus, but the relationship of this species to either $P$. obesus or $G$. christiei is uncertain.

In addition to the type species, and possibly also $P$. acutus Lindström, 1884, Grantlandispira is also known from carbonate mounds from the Lower Silurian of western North Greenland. Preservation of these specimens is mainly in the form of internal moulds in white limestone, and meaningful comparison with $G$. christiei is not currently possible.

\section{Autecology}

Most Silurian gastropods are prosobranchs referred to the Order Archaeogastropoda. Peel (in press) noted that only one twentieth of the gastropods recognised by Knight et al. (1960) from the Silurian were placed within the Order Caenogastropoda (= Mesogastropoda + Neogastropoda), while opisthobranchs and pulmonates are not known from the Silurian. In contrast, prosobranchs account for only half of the living genera of gastropods, with archaeogastropods forming less than half of this fraction (Taylor \& Sohl, 1962). Changes in gastropod faunal composition and the rise of the more advanced mesogastropods and neogastropods have undoubtedly complicated autecological interpretations of Silurian archaeogastropods based on direct comparison with living members of the same order. There is now clear evidence, however, that Palaeozoic archaeogastropods followed life styles only rarely employed by their extant relatives. Peel (1977, 1978, in press) stressed the role of functional morphology in the autecological analysis of Palaeozoic gastropods. Recent studies by Harper \& Rollins (1982), Linsley (1977, 1978), Linsley \& Kier (1984), Linsley \& Peel (1983), McNair et al. (1981) and Signor (1982) are particularly relevant in this connection (additional references in Peel, in press).

A notable feature of Grantlandispira christiei is the shallowly cyrtoconoid spire. Similar coiling is seen in Architectonica Röding, 1799 (fig. 5); this is perhaps reflected in the naming of Pycnomphalus solaroides (Hall, 1852), since Solarium Lamarck, 1799, is a synonym of Architectonica. Architectonica also resembles Grantlandispira with respect to the radial aperture, discussed below, but differs notably in possessing a widely phaneromphalous umbilicus (fig. 5B). Robertson (1970a) described living Indo-Pacific architectonicids with eggs and young in the umbilicus.

The aperture of Grantlandispira and most pycnomphalinid species is approximately radial, i.e., the plane of the aperture includes the axis of coiling. In most anomphalinids, the aperture is tangential, i.e., the plane of the aperture forms a tangent to the gastropod body whorl. Linsley (1977) noted that most living gastropods have tangential apertures enabling the shell to be clamped against the substratum when the animal is disturbed. Those few living gastropods with radial apertures, e.g., Architectonica (fig. 5A,B), are usually sedentary. Radial apertures are more common in the Palaeozoic where a number of species show shell morphologies such as uncoiling or open coiling which also support interpretations of a sedentary existence (Yochelson, 1971; Peel, 1975). 

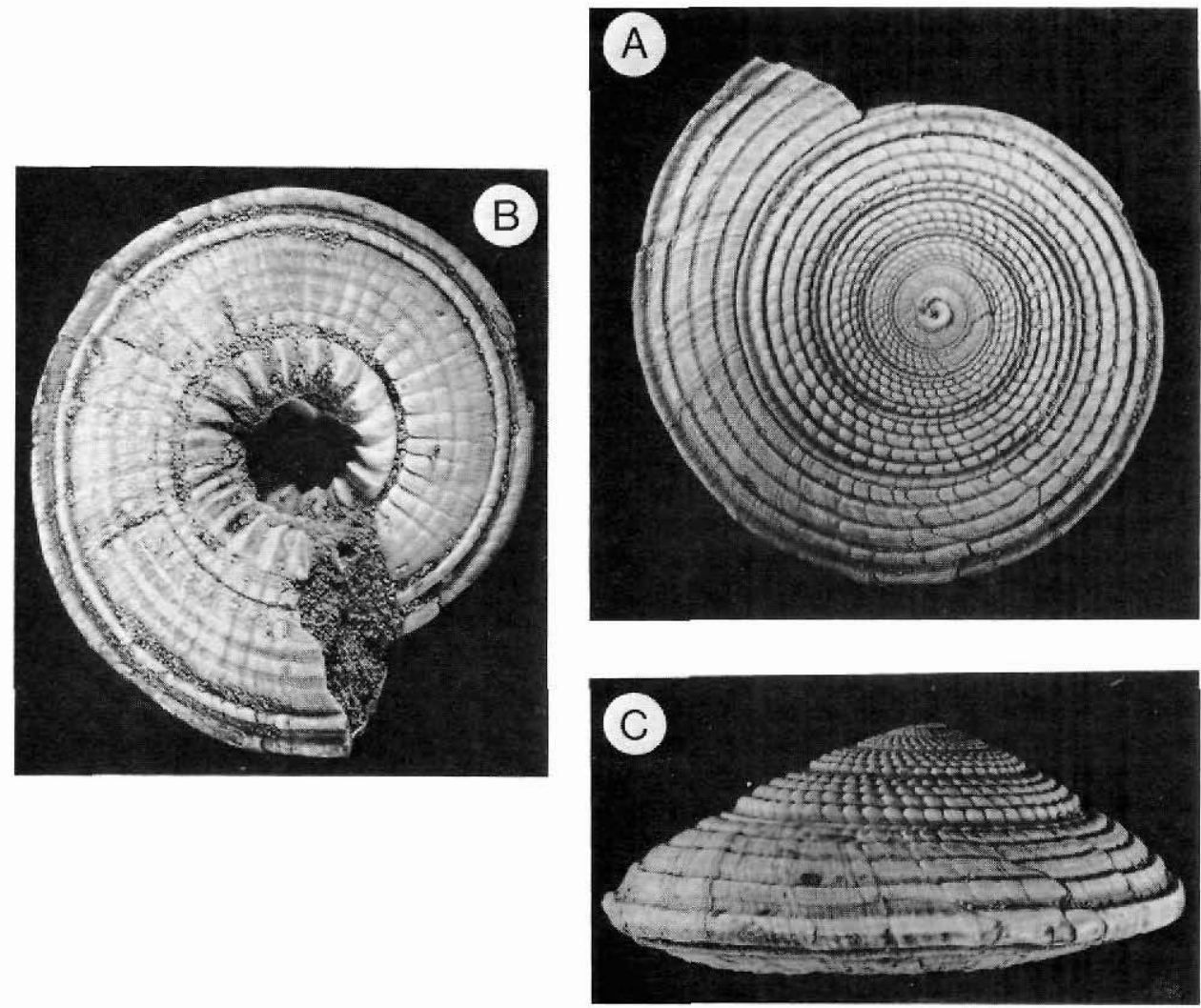

Fig. 5. Architectonica Röding, 1799 from the Tertiary of France, MGUH 16.578, $\times 3$. A, apical view to show the radial aperture. B, basal view showing the open umbilicus; the apertural margin is broken. C, lateral view showing the slightly cyrtoconoid form.

The presence of the radial aperture in Grantlandispira thus suggests a largely sedentary mode of life. Linsley (1977, p. 197) characterised living architectonicids with this apertural form as "exceedingly sedentary" while Robertson (in Linsley, 1977, p. 198) noted that Heliacus d'Orbigny, 1842 "is usually attached to its host and to the substratum with remarkably sturdy but elastic mucous threads; when in situ they are in various positions, including umbilical side up. Thus architectonicids seem unusually indifferent to being upside down". Architectonicids feed on stony corals by means of an unusually long, extensible proboscis (Robertson, 1970b).

The aperture is also radial in Umbonium Link, 1807, a living trochid with a rotelliform shell not unlike Pycnomphalus. $U$. vestiarium is infaunal or semi-infaunal and feeds by filtering seawater as it moves over the surface of the sand, or during the long periods it spends buried, except for its tentacles, eye stalks and siphons (Fretter, 1975). Umbonium also resembles Grantlandispira in closing the umbilicus, but the funicle of the Silurian genus is replaced by a solid callus plug filling the umbilicus entirely (fig. 6). Closure of the 


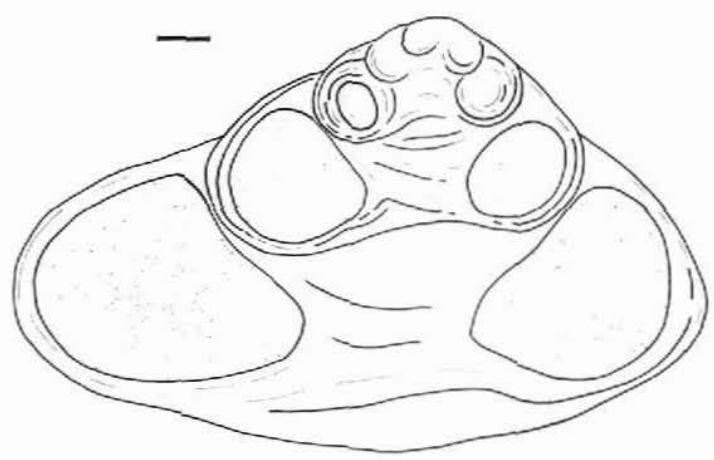

Fig. 6. Camera lucida sketch of ground axial cross-section through Umbonium Link, 1807 showing the callus-infilled umbilicus and prominent secondary thickening of the shell in the early whorls. The spiral cavity inside the shell is stippled. Scale bar is $2 \mathrm{~mm}$.

umbilicus is also seen in some naticids, which are active infaunal shell-borers, suggesting that the feature is related to an infaunal mode of life.

An alternative possibility is that the closure of the umbilicus in Grantlandispira may represent a form of strengthening of the structurally weak shell as a defence against predation. Strengthening of the shell is a clear trend in the Mesozoic - Tertiary evolution of the gastropods (Vermeij, 1983) in partial response to the activities of shell-breaking and shell crushing molluscivores. The abundance of repaired injuries in present-day marine gastropod shells attests to the role of predation in recent gastropod communities. Cases of shell repair in Silurian gastropods are recorded, but Peel (1984) concluded that shell-breaking or shellcrushing by molluscivores during the Silurian was insignificant.

The outer lip of Grantlandispira shows a well developed sinus (fig. 4) interpreted as exhalant in function. The subsutural location of the sinus suggests the presence of a single gill, a condition probably paralleled in contemporaneous euomphalins (see discussion in McLean, 1981). Inhalant currents are considered to have entered the shell near the periphery, to be expelled subsuturally, as in Euomphalopterus (Linsley et al., 1978).

It is not known how Grantlandispira obtained food, although the radial aperture suggests that it was relatively immobile during the process. Enclosing strata of the Offley Island Formation are rich in colonial tabulate corals which may tempt comparison with extant architectonicids living on colonial scleractinian corals (Robertson, 1967, 1970a,b). Closure of the umbilicus, however, seems to favour comparison with the infaunal or semi-infaunal Umbonium which lives by ciliary feeding. $U$. vestiarium is the only known living ciliary feeding archaeogastropod, although this form of feeding is employed by a number of more advanced prosobranchs. In this connection, it has atypically developed a monopectinate gill. The monopectinate gill is otherwise characteristic of mesogastropods and neogastropods. while a bipectinate gill(s) is present in archaeogastropods. A number of Palaeozoic supposed archaeogastropods have been interpreted as ciliary feeders (Yochelson, 1971; Peel, 1975, in press; McLean, 1981), while this ecological niche is now largely occupied by mesogastropods. Grantlandispira is multi-whorled with a slow rate of whorl expansion. Andrews (1974) suggested that these shell characteristics in the high spired Turritella might reflect its 
ciliary feeding mode of life, a suggestion which further supports the conclusion that Grantlandispira was probably an infaunal, or semi-infaunal, sedentary, ciliary feeding gastropod.

Acknowledgements. Esben Glendal and Bente Thomas assisted in preparation of the manuscript.

\section{References}

Andrews, H. E. 1974: Morphometrics and functional morphology of Turritella mortoni. J. Paleont. 48, 1126-1140.

Christic, R. L. 1966: Operation Grant Land. Pap. geol. Surv. Can. 66-1, 3-4.

Dawes, P. R. this report: Operation Grant Land 1965-1966; a geological exploration programme in Ellesmere Island and North Greenland. Rapp. Gronlands geol. Unders. 121, 5-17.

Dawes, P. R. \& Peel, J. S. this report: Biostratigraphic reconnaissance in the Lower Palaeozoic of western North Greenland. Rapp. Grønlands geol. Unders. 121, 19-51.

Dietz, E. 1911: Ein Beitrag zur Kenntnis der deutschen Zechsteinschnecken. Jahr. König. Preus. Geol. Land. Berlin 30, 444-506.

Fretter, V. 1975: Umbonium vestiarium, a filter feeding trochid. J. Zool. 177, 541-552.

Harper, J. A. \& Rollins, H. B. 1982: Recognition of Monoplacophora and Gastropoda in the fossil record: a functional look at the bellerophont controversy. Proc. IIIrd N. Am. Paleont. Convention 1, 227-232.

Hurst, J. M. 1980: Silurian stratigraphy and facies distribution in Washington Land and western Hall Land, North Greenland. Bull. Grønlands geol. Unders. 138, 95 pp.

Knight, J. B. 1941: Paleozoic gastropod genotypes. Spec. Pap. Geol. Soc. Am. 32, 1-510.

Knight, J. B., Cox, L. R., Keen, A. M., Smith, A. G., Batten, R. L., Yochelson, E. L., Ludbrook, N. H., Robertson, R., Yonge, C. M. \& Moore, R. C. 1960: Mollusca 1. In Moore, R. C. (edit.) Treatise on Invertebrate Paleontology I. Geol. Soc. Am.; Univ. Kansas Press, 351 pp.

Lindström, G. 1884: On the Silurian Gastropoda and Pteropoda of Gotland. Handl. Svenska Vetenskap Akad. 19, $250 \mathrm{pp}$.

Linsley, R. M. 1977: Some "laws" of gastropod shell form. Paleobiology 3, 196-206.

Linsley, R. M. 1978: Shell form and the evolution of gastropods. Am. Sci. 66, $432-441$.

Linsley, R. M. \& Kier, W. M. 1984: The Paragastropoda: a proposal for a new class of Paleozoic Mollusca. Malacologia 25, 241-254.

Linsley, R. M. \& Peel, J. S. 1983: Gonad pouches in a new clam-like monoplacophoran from the Silurian of Sweden. Lethaia 16, 273-280.

Linsley, R. M., Yochelson, E. L. \& Rohr, D. M. 1978: A reinterpretation of the mode of life of some Paleozoic frilled gastropods. Lethaia 11, 105-112.

McLean, J. H. 1981: A new monoplacophoran limpet from the continental shelf off southern California. Los Angeles Nat. Hist. Mus. Contribs Sci. 307, 19 pp.

McNair, C. G., Kier, W. M., LaCroix, P. D. \& Linsley, R. M. 1981: The functional significance of aperture form in gastropods. Lethaia 14, 63-170.

Peel, J. S. 1975: A new Silurian gastropod from Wisconsin and the ecology of uncoiling in Palaeozoic gastropods. Bull. geol. Soc. Denmark 24, 211-221.

Peel, J. S. 1977: Systematics and palaeoecology of the Silurian gastropods of the Arisaig Group, Nova Scotia. Biol. Skr. Dan. Vid. Selsk. 21,2, 1-89.

Peel, J. S. 1978: Faunal succession and mode of life of Silurian gastropods in the Arisaig Group, Nova Scotia. Palaeontology 21, 285-306.

Peel, J. S. 1984: Attempted predation and shell repair in Euomphalopterus (Gastropoda) from the Silurian of Gotland. Bull. geol. Soc. Danmark 32, 163-168. 
Peel, J. S. in press: Autecology of Silurian gastropods and monoplacophorans. Spec. Pap. Palaeontology 32.

Robertson, R. 1967: Heliacus (Gastropoda: Architectonicidae) symbiotic with Zoanthiniaria (Coelenterata). Science 156, 246-248.

Robertson, R. 1970a: Systematics of Indo-Pacific Philippia (Psilaxis), architectonicid gastropods with eggs and young in the umbilicus. Pacific Science 24, 66-83.

Robertson, R. 1970b: The feeding, larval dispersal, and metamorphosis of Philippia (Gastropoda: Architectonicidae). Pacific Science 24, 55-65.

Signor, P. W. 1982: Resolution of life habits using multiple morphological criteria: shell form and lifemode in turritelliform gastropods. Paleobiology 8, 378-388.

Taylor, D. W. \& Sohl, N. F. 1962: An outline of gastropod classification. Malacologia 1, 7-32.

Vermeij, G. J. 1983: Shell-breaking predation through time. In Tavesz, M. J. S. \& McCall, P. L. (edit.) Biotic interactions in recent and fossil benthic communities, 649-669. Plenum.

Whiteaves, J. F. 1895: Revision of the fauna of the Guelph Formation of Ontario, with descriptions of a few new species. Palcoozoic Fossils 3,2, 45-109. Geol. Surv. Canada.

Yochelson, E. L. 1971: A new late Devonian gastropod and its bearing on problems of open coiling and septation. Smithson. Contr. Paleobiol. 3, 231-241. 